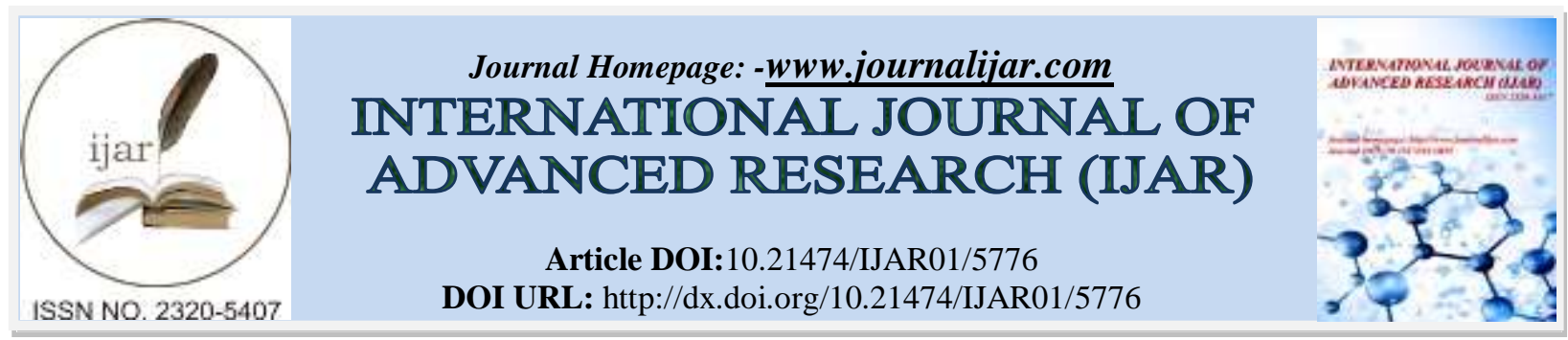

RESEARCH ARTICLE

\title{
ANTICONVULSANT EFFECT OF ETHANOLIC EXTRACT OF TRIGONELLA FOENUM GRAECUM LINN. AND SODIUM VALPROATE - A COMPARATIVE STUDY IN ALBINO MICE.
}

\section{Dr. Tarun Kumar ${ }^{1}$, Dr. P.Shyamasakhi Devi ${ }^{2}$, Dr. Priyotosh Banerjee ${ }^{3}$ and Dr. N. Meena Devi ${ }^{4}$.}

1. Post graduate Junior Resident, Department of Pharmacology, Regional Institute of Medical Sciences, Imphal.

2. Associate Professor, Department of Pharmacology, Regional Institute of Medical Sciences, Imphal.

3. Post graduate Junior Resident, Department of Pharmacology, Regional Institute of Medical Sciences, Imphal.

4. Professor, Department of Pharmacology, Regional Institute of Medical Sciences, Imphal.

\section{Manuscript Info}

Manuscript History

Received: 05 September 2017

Final Accepted: 07 October 2017

Published: November 2017

Key words:-

Anticonvulsant, Trigonella, Valproate,

Maximal electroshock seizure.

\begin{abstract}
This study was undertaken to compare the anticonvulsant property of ethanolic extract of Trigonella foenum graecum Linn. (TFG) plant and sodium valproate in albino mice by comparing the duration of hind limb tonic extension (HLTE) phase after maximal electroshock seizure (MES). Thirty albino mice of either sex weighing between 20-30g were screened and divided into 5 groups of 6 mice each. Group1(control) was given $1 \%$ gum acacia in distilled water at a volume of $2 \mathrm{ml} / 100 \mathrm{~g}$ body wt. orally. Group 3, 4 and 5 were given ethanolic extract of TFG at doses of 100, 200 and $400 \mathrm{mg} / \mathrm{kg}$ respectively. Group 2 (standard) was given sodium valproate $-300 \mathrm{mg} / \mathrm{kg}$. All the drugs were suspended in $1 \%$ gum acacia solution and given at the volume of $2 \mathrm{ml} / 100 \mathrm{~g} /$ day orally. After 1 hour of drug administration, mice were subjected to MES by an electrical stimulus of $50 \mathrm{~mA}$ of alternating current from an electro-convulsiometer for $0.2 \mathrm{sec}$ via ear clip electrodes. Animal passed through various phases : tonic flexion, tonic extension, clonic convulsions, stupor, and recovery or death. Disappearance or shortening of hind limb tonic extension phase was taken as the percentage of protection. The data was analysed by one way ANOVA followed by Dunnett's ' $\mathrm{t}$ ' test and study showed significant anticonvulsant property of test drug as compared to standard.
\end{abstract}

Copy Right, IJAR, 2017,. All rights reserved.

\section{Introduction:-}

The human nervous system is a complex structure. It coordinates and regulates the functioning of all body organs. ${ }^{1}$ Drugs acting on central nervous system are among the first to be discovered by the primitive human and are still the most widely used group of the pharmacological agents. ${ }^{2}$ Epilepsy is characterised by a group of disorders with recurrent episodes of seizures owing to a chronic underlying process. ${ }^{[3,4]}$ It is affecting $1-2 \%$ of the world population. The lifetime risk of seizures is $5 \%$ but highest risk is at the extremes of age. ${ }^{4}$ More than $20 \%$ of patients exhibit uncontrolled seizures in spite of availability of a number of antiepileptics. ${ }^{[6,7]}$ Current antiepileptics can cause side effects like teratogenicity, chronic toxicity and adversely affect cognition and behaviour. ${ }^{[8,9,10]}$ Hence there is a need of development of safe and effective antiepileptic drug having none or less side effects. Several plant extracts exhibit the potential to be developed into newer antiepileptics. The treatment and control of diseases by using locally 
available medicinal plants will continue to play significant roles in developing countries. Therefore, it becomes pertinent to validate and evaluate the claims of medicinal plants used in healing practices in order to provide a scientific basis for their use and also to optimise their safety and efficacy probably through isolation of their bioactive principles responsible for the observed therapeutic effect.

\section{Trigonella Foenum-Graecum Linn.:-}

TFG of the family Fabaceae is commonly found in many parts of India, Asia and Middle east. It is known as Fenugreek in English and as Methi in Hindi. It is a perennial herbaceous plant growing upto 1-11/2 ft in height with trifoliate or obovate leaflets. The stalkless flowers are yellow and located in the axils. The seeds which taste bitter are found in the compressed pod. The seeds contain essential fatty oil $6 \%$, resin and mucilage $28 \%$, albumin $22 \%$, several alkaloids like choline, trigonelline, neurin, betain. It also contains flavonoids, steroidal saponins especially diosgenin, iron, plenty of fibers, non essential amino acids like 4-hydroxy isoleucin.

In the Indian system of medicine Ayurveda, TFG was used as a tonic, carminative and to cure cold, sore throat, chronic cough, diarrhoea, dysentery, etc.

The flour of the seeds was used as a poultice to gouty pains, neuralgia, sciatica and skin irritation. Its pessaries are used to treat leucorrhoea. The poultice of leaves was used to treat external swellings. As an application to head it promotes hair growth and prevent hair fall.

Kritikar KR. ${ }^{11}$ :-

Explained about the use of the fenugreek plant and its seeds as diuretic emmenagogue and used in dropsy.

Sharma RD. et al. ${ }^{12}$ :-

Demonstrated the effects of TFG seeds on blood glucose and serum lipids in Type I DM. Fenugreek diet significantly reduced fasting blood sugar and improved glucose tolerance test. These results indicated the usefulness of fenugreek seeds in the management of diabetes.

Sauvaire Y. et al. ${ }^{13}$ :-

Explained TFG seed extract containing steroid saponin alone or together with diosgenin was observed to have hypolipidemic effect in diabetic dogs.

Ravikumar P. et al. ${ }^{14}$ :-

Evaluated the antioxidant properties of fenugreek (TFG) on alloxan-diabetic rats.

Bin-Hafeez B. et al. ${ }^{15}$ :-

Evaluated the immunostimulatory effect of aqueous extract of TFG in mice.

RajuJ. et al. ${ }^{16}:-$

suggested the chemopreventive effects of fenugreek seeds against colon cancer.

EldinIMT. et al. ${ }^{17}$ :-

Exlained about the in vitro anticoagulant effect of fenugreek (TFG) in blood samples of normal Sudanese individuals.

Manasa MR. et al. ${ }^{18}$ :-

Explained about the Anticonvulsant action of aqueous extract of Centella asiatica and sodium valproate-A comparative study in pentylenetetrazole-induced seizures.

\section{Materials And Methods:-}

Materials:-

For preparation of the plant extract:-

Dried Trigonella foenum graecum Linn. plants, Mixer grinder, Soxhlet apparatus from Kerone company, Mumbai, Petroleum ether (B.P- $\left.40^{\circ}-60^{\circ} \mathrm{C}\right)$ from HPLC lab reagents, Ethanol 95\% (B.P - $\left.77^{\circ} \mathrm{C}\right)$, Evaporating Dish. 


\section{For seizure model:-}

Albino mice, Electro-convulsiometer (Techno electronics, Lucknow; Instrument no. C-2, S1. No. 710510), Ear clip electrodes, Stop watch, Markers, Syringes, Distilled water, Feeding tubes, Gum acacia (GA), Sodium valproate tablets - VALPROL-CR-300, Weighing machine and Electronic balance (Shimadzu, Japan; No. D455007340).

\section{Methods:- \\ Authentication and Collection of plant material:-}

TFG plants were collected from the valley areas of Imphal West District, Manipur in the month of June 2017 and got authenticated from Department of Life Sciences, Manipur University, Canchipur as Trigonella foenum graecum Linn. species with Ac. No. MUMP 3627. The whole experiment was conducted in Department of Pharmacology, RIMS after getting clearance from the Institutional Animal Ethics Committee, RIMS, Imphal and acute toxicity studies were done according to the OECD guidelines 423 and no mortality was seen upto $2000 \mathrm{mg} / \mathrm{kg}$ body wt. p.o. of the test drug.

\section{Extraction of plant material:-}

Powdered shade dried plants were defatted using petroleum ether and then the ethanolic extract was prepared using Soxhlet apparatus and the yield was found to be $14 \%$.

\section{Experimental Animals:-}

Healthy albino mice of either sex weighing approximately $25-30 \mathrm{~g}$ were used and these animals were obtained from the Central Animal House, RIMS, Imphal and were acclimatized in the departmental animal room for 7 days before the experiment. They were housed in groups of six mice per cage under the natural light-dark cycle at room temperature with free access to standard mice feed and water ad libitum.

\section{Selection of animals:-}

Screening of the mice was done with a current of $50 \mathrm{~mA}$ for $0.2 \mathrm{~s}$ via a pair of ear clip electrodes (trans auricular) using an electro-convulsiometer. The occurrence of hind limb tonic extension (HLTE) will be taken as a positive response for MES. HLTE is defined by hind limb extension more than $90^{\circ}$ from the body and sustaining for more than $3 \mathrm{sec}$ following $10 \mathrm{sec}$ after the stimulation. ${ }^{19}$ Thirty mice which showed HLTE were selected for the study.

\section{Experimental design:-}

Selected animals will be allocated into 5 groups of 6 mice each and treated as follows:

Group I : Control (1\% gum acacia in D/W)

Group II: Sodium valproate - $300 \mathrm{mg} / \mathrm{kg}$

Group III: Ethanolic extract of TFG - $100 \mathrm{mg} / \mathrm{kg}$

Group IV: Ethanolic extract of TFG - 200mg/kg

Group V: Ethanolic extract of TFG - 400mg/kg

The standard and the test drugs were suspended in $1 \%$ gum acacia solution. Volume of administration for all the animals was kept constant at $2 \mathrm{ml} / 100 \mathrm{~g}$ body wt. p.o. Except for the short duration of experimentation, the animals were allowed for free access to food and water. This experiment was carried out in quiet room under controlled light condition between 11:00 am and 3:00 pm. Each animal will be tested only once and then all the animals were treated as per the experimental design. After 1 hour of drug administration mice were subjected to MES as described above. The percentage protection was calculated as follows:

$$
\% \text { Protection }=\frac{\text { Duration of HLTE in control }- \text { Duration of HLTE in test/standard }}{\text { Duration of HLTE in control }} \times 100
$$

\section{Disposal of Animal carcasses:-}

The carcasses of animals which died during the experiment were disposed by deep burial method covered with lime and disinfectants.

\section{Result and discussion:-}

The anticonvulsant effect of TFG are shown in table. The datas were analysed by one way ANOVA followed by Dunnett's ' $t$ ' test using spss version 21 where $p<0.05$ was considered statistically significant. Hind limb tonic extension (HLTE) duration and \% protection were determined and expressed as mean \pm SEM. The test drug at different doses and standard were compared with control and found to be highly significant. Test drug (100mg/kg 
body wt.) showed highly significant effect when compared with standard while test drug at 200 and $400 \mathrm{mg} / \mathrm{kg}$ body wt. are statistically not significant, which indicates comparable effect as that of standard.

Table:- Anticonvulsant effect of ethanolic extract of TFG on albino mice

\begin{tabular}{|c|c|c|}
\hline Group & HLTE duration in sec & \% Protection \\
\hline 1-Control & $16.35 \pm 0.15$ & $0.00 \pm 0.00$ \\
\hline 2-Standard(300mg/kg) & $9.04 \pm 0.03^{*}$ & $44.74 \pm 0.17^{*}$ \\
\hline 3-Test 1(100mg/kg) & $10.85 \pm 0.10^{*+}$ & $33.67 \pm 0.58^{*+}$ \\
\hline 4-Test 2(200mg/kg) & $8.97 \pm 0.06^{*}$ & $45.12 \pm 0.36^{*}$ \\
\hline 5-Test 3(400mg/kg) & $8.62 \pm 0.32^{*}$ & $47.28 \pm 1.93^{*}$ \\
\hline
\end{tabular}

One way ANOVA followed by Dunnett's t test, $\mathrm{F}=384.8, \mathrm{df}=4, \quad \mathrm{P}$ value $=<0.001$

Values are Mean \pm SEM , $\mathrm{n}=6$

* $\mathrm{P}<0.001$ when compared with control

$+\mathrm{P}<0.001$ when compared with standard

\section{Conclusion:-}

MES model is a standard method for determining anticonvulsant activity. The study showed significant anticonvulsant property of test drug TFG which is comparable with that of sodium valproate.

\section{References:-}

1. Barar FSK. Textbook of Pharmacology. New Delhi: S. Chand \& Company Ltd; 2013.

2. Suba V, Murugesan T, Rao RB, Pal M, Mandal SC, Saha BP. Neuropharmacological profile of Barlerialupulina Lindl. extract in animal models. J Ethnopharmacol 2002;8(2):251-5.

3. Lowenstein DH. Seizures and epilepsy. In:(Eds.). Harrison's Principles of Internal Medicine, vol2, 19th edn., New York: McGraw-Hill, 2015.pp. 2542-59.

4. Leach JP, Davenport RJ. Neurological disease. In: (Eds.). Davidson's Principles and Practice of Medicine. 22nd edn, New York: Churchill Livingstone Elsevier, 2014.pp. 1137-230.

5. Aminoff MJ, Kerchner GA. Nervous system disorders. In: (Eds.). Current Medical Diagnosis and Treatment, 54th edn, New York: McGraw-Hill, 2015:954-1026.

6. Liao Wp, Chen L, Yi YH, Su T. Study of antiepileptic effect of extracts from Acorustatarinowii Schott. Epilepsia 2005;46(Supp11):S21-4.

7. Sinoriva P, Irchhaiya R, Sharma B, Sahu G, Kumar S. Anticonvulsant and muscle relaxant activity of the ethanolic extract of stemsa of Dendrophthoefalcata (Linn. F.) in mice. Indian J Pharmacol 2011;43(6):710-3.

8. Mathur S, Sen S, Ramesh L, Satish Kumar M. Utilization pattern of antiepileptic drugs and their adverse effects in a teaching hospital. Asian J PharmaceutClin Res 2010;3(1):55-9.

9. Aldenkamp AP. Cognitive side effects of antiepileptic drugs. Neuropsychol Childhood Epilep 2006;50:257-67.

10. Sutar RC, Kasture SB, Kalaichelvan VK. Evaluation of anticonvulsant activity of leaf extracts of Holopteleaintegrifolia (Roxb.)planch in experimental animals. Int J Pharm PharmSci 2014;6(4):308-11.

11. Kirtikar KR, Basu BD. Indian Medicinal Plants. Dehradun: International Book Distributors;1999(8).

12. Sharma RD, Raghuram TC, Rao NS. Effects of fenugreek seeds on blood glucose and serum lipids in Type 1 diabetes. Eur J ClinNutr 1990;44(4):301-6.

13. Sauvaire Y, Ribes G, Baccou JC, Loubatieeres-Mariani MM. Implication of Steroid Saponins and Sapogenins in the Hypocholesterolemic effect of fenugreek. Lipids 1991;26(3):191-7.

14. Ravikumar P, Anuradha CV. Effect of fenugreek seeds on blood lipid peroxidation and antioxidants in diabetic rats. Phytother Res 1999;13(3):197-201.

15. Bin-Hafeez B, Haque R, Parvez S, Panday S, Sayeed I, Raisuddin S. Immunomodulatory effects of fenugreek (Trigonellafoenumgraecum L.) extract in mice. Intimmunopharmacol 2003;3(2):257-65.

16. Raju J, Patlolla JM, Swamy MV, Rao CV. Diosgenin, a steroid saponin of Trigonella induced aberrant crypt foci formation in F 344 rats and induces apoptosis in HT-29 human colon cancer cells. Cancer Epidemol Biomarkers Prev 2004;13(8):1392-8.

17. Eldin IMT, Abdalmutalab MM, Bikir HE. An in vitro anticoagulant effect of Fenugreek (Trigonellafoenumgraecum) in blood samples of normal Sudanese individuals. Sudanese J of Paediatrics 2013;13(2):52-6. 
18. Manasa MR, Sachin ID. Anticonvulsant action of aqueous extract of Centellaasiatica and sodium valproate-A comparative study in pentylenetetrazole-induced seizures. National Journal of Physiology, Pharmacy and Pharmacology 2016;6(2):128-31.

19. Castel-Branco MM, Alves GL, Figueiredo IV, Falcao AC, Caramona MM. The maximal electroshock seizure (MES) model in the preclinical assessment of potential new antiepileptic drugs. Methods Find ExpClinPharmacol 2009;31(2):101-6. 